\title{
Letter
}

\section{Understanding conservation marketing and focusing on the best available evidence: a reply to Hobson}

We thank Hobson (2016) for raising important questions about evidence for the impact of social and conservation marketing initiatives. There is a clear need for more rigorous evaluation of all behaviour change initiatives that focus on biodiversity and the environment. Yet we feel it is vital to dispel any misunderstandings around the different ways marketing is used to support environmental sustainability and to ensure a clear emphasis on the best available evidence.

It is often assumed that because commercial marketing is focused on consumption and monetary transactions, the use of marketing in a social or conservation context must have the same emphasis. This is not the case. As with the now well established use of social marketing in public health, the focus of conservation marketing is social change. This has included, amongst others, driving the adoption of fuel-efficient cooking stoves to reduce deforestation, establishing reciprocal water agreements to improve watershed management, and reinforcing local customary laws around sustainable fishing (see references in Veríssimo, 2013). Matters such as donations have been the remit of another marketing field, non-profit marketing.

The confusion around the scope of conservation marketing is understandable, given the myriad of often fuzzily defined terms, such as social media marketing and green marketing, which have spread through the literature. The community of social marketing practitioners has addressed this challenge through its Declaration of Social Marketing's Unique Principles and Distinctions, which sets out social marketing's unique value proposition (Lee \& Kotler, 2011). It is perhaps time for the community of practice around conservation marketing to follow a similar path, after the recent proposition of a definition for the field (Wright et al., 2015).

Regarding the impact of conservation marketing, we are interested by the reference to a 'strong empirical evidence base' for the notion that marketing has been ineffective in an environmental context. We regret that Hobson (2016) does not cite any empirical studies to support this assertion. In fields such as public health the best available evidence, in the form of systematic reviews (e.g. Stead et al., 2007), shows that marketing interventions can lead to positive outcomes in a diversity of contexts and target groups. Conservation marketing interventions have suffered historically from a lack of robust evaluation and so the available evidence is not as strong, yet to the best of our knowledge the best available evidence supports the view that marketing can be an important tool for biodiversity management (see references in Veríssimo, 2013).

It is therefore not surprising that there is a growing interest in conservation marketing amongst conservationists, many of whom are social scientists. This is showcased by the creation and growing membership of the Society for Conservation Biology's Conservation Marketing and Engagement Working Group (Wright et al., 2015), which since December 2014 has gathered more than 250 members. Simultaneously, conservation marketing is increasingly becoming established and being recognized as part of the social science fields of conservation science (Bennett et al., 2016).

Nonetheless, we acknowledge that, as with any approach, there are contexts where a marketing-based approach may not succeed. This realization is in line with marketing principles: a basic tenet of the field is that there are no one size fits all solutions. Conservation marketing is one field of many seeking to achieve positive change for biodiversity conservation.

Diogo VerísSIMo* (Corresponding author) Department of Geography and Environmental Engineering, Whiting School of Engineering, Johns Hopkins University, Maryland 21218, USA E-mail verissimodiogo@gmail.com

EMma McKINLEY Business School, University of Chichester, Bognor Regis, UK

${ }^{*}$ Also at: Rare, Arlington, Virginia, USA

\section{References}

Bennett, N.J., Roth, R., Klain, S.C., Chan, K.M.A., Clark, D.A., Cullman, G. et al. (2016) Mainstreaming the social sciences in conservation. Conservation Biology, dx.doi.org/10.1111/cobi.12788.

Hobson, K. (2016) Why the devil does not have the best tunes: a response to Verissimo and McKinley. Oryx, dx.doi.org/10.1017/ Soo30605316000326.

Lee, N.R. \& Kotler, P. (2011) Defining social marketing. In Social Marketing: Influencing Behaviors for Good, 4 th edition (eds N.R. Lee \& P. Kotler), pp. 2-31. Sage Publications, Thousand Oaks, USA.

Stead, M., Gordon, R., Angus, K. \& McDermott, L. (2007) A systematic review of social marketing effectiveness. Health Education, 107, 126-191.

Veríssimo, D. (2013) Influencing human behaviour: an underutilised tool for biodiversity management. Conservation Evidence, 10, 29-31.

Wright, A.J., Veríssimo, D., Pilfold, K., Parsons, E.C.M., Ventre, K., Cousins, J. et al. (2015) Competitive outreach in the 21st century: why we need conservation marketing. Ocean and Coastal Management, 115, 41-48. 